\title{
SWOT analýza modernizace úpravny vody Želivka
}

\section{PETR TUŠIL}

\author{
Klíčová slova: SWOT analýza - modernizace - granulované aktivní uhlí (GAU) - úpravna vody
}

\section{SOUHRN}

Následující článek je zaměřen na aplikaci postupů SWOT analýzy pro konkrétní řešení modernizace úpravny vody Želivka. Cílem SWOT analýzy bylo zhodnotit navrhované a definované varianty technického řešení modernizace úpravny vody Želivka a současně vytvořit relevantní podklad pro následné rozhodování Členů statutárních orgánů vlastníka - společnost Úpravna vody Želivka, a. s., a provozovatele - společnost Želivská provozní, a. s., při projednávání investiční a provozní strategie pro následující období 10-15 let.

\section{ÚVOD}

SWOT analýza je metoda, pomocí které je možno identifikovat silné (Strengths) a slabé (Weaknesses) stránky, př́ležitosti (Opportunities) a hrozby (Threats) spojené s určitým projektem, typem podnikání, podnikatelským záměrem, strategickou investicí a politikou (ve smyslu opatření). Jedná se o metodu analýzy užívanou především v marketingu, ale také např. príi analýze a tvorbě politik (policy analysis). Díky tomu je možné komplexně vyhodnotit fungování firmy, nalézt problémy nebo nové možnosti růstu. Je rovněž součástí strategického (dlouhodobého) plánování společnosti. V našem prípadě bude využita pro rozhodování při volbě optimální varianty modernizace technologické linky úpravy surové vody na úpravně vody Želivka. Cílem SWOT analýzy bylo posoudit vhodnost variantních řešení realizace 2. stavby - sorpce na GAU [1].

Úpravna vody Želivka (dale jen úv Želivka) (obr. 1) byla vybudována ve dvou etapách ve druhé polovině 20. století. Celkový návrh technologie úpravy vody byl koncipován $\vee 60$. letech s ohledem na stav kvality surové vody ve zdroji (vodárenská nádrž Švihov), ale respektoval i očekávaný vývoj kvality vody $\checkmark$ budoucnosti. Rozhodujícím faktorem pro návrh technologie úpravy vody byly i požadavky na jakost pitné vody $v$ době výstavby. Jakost surové vody ve vodárenské nádrži Švihov (dale jen VN Švihov) prošla za dobu existence úpravny velkým vývojem. Významný vliv na kvalitu vody má režim hospodaření v okolí nádrže, životní styl obyvatel, klimatické změny apod. Rozsah a koncentrační úroveň sledovaných parametrů je dána aktuálně platnými právními předpisy EU, resp. ČR, dostupností a citlivostí analytických metod. Navrhovaná opatření investičního charakteru patří k největším modernizačním zásahům $\checkmark$ historii úpravny, jejichž hlavním cílem je velmi výrazné zlepšení kvality pitné vody, eliminace negativních faktorů, především pesticidních látek, a zvýšení bezpečnosti výroby nepodléhající tolik vnějším vlivưm. Zásadním informačním zdrojem pro zpracování SWOT analýzy byl materiál „P Príprava a modernizace ÚV Želivka - studie souboru staveb (PL 1401401), Sweco Hydroprojekt, a. S., listopad 2014, Praha" [2]. Dalšími informačními podklady byly materiály a prezentace pro zasedání správních orgánů společnosti Úpravna vody Želivka, a. s. (ÚvŽ).
Vzhledem ke skutečnosti, že ÚVŽ hodlá klíčovou část modernizace (technologický stupeň sorpce na GAU) z větší části realizovat z podpory Operačního programu Životní prostředí, byl důležitým podkladem i Programový dokument Operačního programu Životní prostředí (dále jen OPŽP) a Pravidla pro žadatele a př́ijemce podpory v OPŽP v období 2014-2020 [3, 4].

\section{ZÁKLADNÍ CHRAKTERISTIKY MODERNIZACE A REKONSTRUKCE}

Hlavním cílem modernizace a rekonstrukce ÚV Želivka jsou tyto skutečnosti a předpoklady:

— odstranění specifických organických látek (xenobiotik, pesticidů, farmak atd.) a jejich rozkladných produktů, které jsou obsaženy v surové vodě anebo které vznikají při průchodu technologií úpravy, např. při ozonizaci;

- minimalizace rizika nesplnění legislativních limitů pro pesticidní látky a jejich relevantní metabolity ve vyrobené pitné vodě;

— zlepšení parametru "mikroskopický obraz" vyráběné pitné vody v období tzv. jarního oživení ve vodárenské nádrži Švihov (VN Švihov) - období cca 3-5 měsíců v roce;

— zlepšení parametrů vyráběné vody v ukazatelích celkový organický uhlík (TOC), asimilovatelný organický uhlík (AOC), biologicky rozložitelný organický uhlík (BDOC);

- zlepšení chutových ukazatelů vody;

— snižení bezpečnostních rizik v běžném provozu a při krizových situacích zajištění kvality vyrobené vody v souladu s platnými právními předpisy po celý rok;

— omezení rizika prípadného zhoršení kvality odebírané surové vody z VN Švihov.

Plánovaná modernizace a rekonstrukce úv Želivka tvoří ucelený soubor staveb a zahrnuje souhrn následujících klíčových opatření:

- rekonstrukce prvního separačního stupně úpravy s cílem zlepšit separaci suspenze na pískových filtrech;

- doplnění technologické linky úpravy vody o nový technologický stupeň - sorpci na granulovaném aktivním uhlí (GAU), s cílem zajistit odstranění specifických organických látek - zejména pesticidů a jejich metabolitů, u nichž již v současnosti dochází k překračování limitních koncentrací v surové vodě a v budoucnosti hrozí riziko překračování koncentrací těchto látek i ve vyrobené pitné vodě. 


\section{Přehled návrhových parametrů nového technologického stupně sorpce na GAU}

Klíčovou částí modernizace a rekonstrukce ÚV Želivka a doplnění technologické linky je realizace výstavby filtrů s GAU, která by měla být schopna plnit tyto zásadní technologické návrhové parametry [2]:

- průtok max. $3,5 \mathrm{~m}^{3} \cdot \mathrm{s}^{-1}$,

- doporučená filtrační rychlost - do $7 \mathrm{~m} / \mathrm{hod}$,

- doba zdržení vody - minimálně 12 minut na GAU.

\section{Posuzované varianty technického řešení modernizace ÚV Želivka}

Pro realizaci modernizace úV Želivka bylo v rámci Studie souboru staveb navrženo celkem pět variantních řešení [2]. Z následných odborných diskusí v širším týmu odborníků a zhodnocení těchto pěti variant byly vybrány pouze dvě, přičemž k nim byla dodatečně doplněna i třetí tzv. redukovaná varianta. Popis technických charakteristik v rámci SWOT analýzy se týkal následujících vybraných tři variantních řešení doplnění sorpce na filtrech s GAU.

Varianta II - realizace v této variantě:

- rekonstrukce stávajícího meandru v objektu BUDAFLO (1. stavba - 1. etapa),

- rozšírení stávajícího meandru do prostoru $v$ současnosti nevyužívaných vápenných sytičů (1. stavba - 2. etapa),

- prestavba linky rychlého míchání v hale filtrace F2 na meandr (1. stavba - 2. etapa),

- prestavba 12 filtrů v hale filtrace F2 (v současnosti filtrů s pískovou náplní) na filtry s náplní GAU (2. stavba) - zbývajících 12 ks pískových filtrů bude provozováno jako první separační stupeň,

- výstavba čerpací stanice zajištující prečerpávání upravené vody na filtry s GAU (2. stavba),

- výstavba všech dalších souvisejících objektů - nového objektu trafostanice a rozvoden vysokého napětí (VN) a nízkého napětí (NN) a nových spojovacích rozvodů (2. stavba),

- rekonstrukce 32 ks pískových filtrů v hale filtrace F1 (3. stavba),

— rekonstrukce zbývajících 12 ks pískových filtrů v hale filtrace F2, které nebyly ve 2. stavbě prestavěny na filtry s náplní GAU (4. stavba) - tato stavba může být realizována současně s 1. a 2. stavbou.

Realizací této varianty by zůstaly zachovány dvě zrekonstruované samostatné technologické linky:

- linka prípravy suspenze v objektu BUDAFLO a 32 ks pískových filtrů v hale filtrace F1,

- linka prípravy suspenze v hale filtrace F2 a 12 ks pískových filtrů v hale filtrace F2,

- pro obě linky by se využíval sorpční stupeň - 12 ks rekonstruovaných filtrů $\checkmark$ hale filtrace F2, návrhové parametry uvádí tabulka 1 .

PInění návrhových parametrů sorpce na GAU při variantě II - filtry s náplní GAU - přestavba 12 ks filtrů v hale filtrace $F 2$ na filtry s náplní GAU - výška náplně 1,8 m - uvádí tabulka 1.

Na základě hodnot uvedených $v$ tabulce 1 nebudou v rámci realizace varianty II zajištěny požadované návrhové parametry technického řešení, při prütoku sorpčním stupněm větším než $3,0 \mathrm{~m}^{3} / \mathrm{s}$ bude doba zdržení na GAU $<12$ minut, filtrační rychlost překročí požadovaných $7 \mathrm{~m} /$ hod již při průtoku $2,5 \mathrm{~m}^{3} / \mathrm{s}$.

Varianta III - součástí této varianty je:

- rekonstrukce stávajícího meandru v objektu BUDAFLO (1. stavba - 1. etapa),

- přestavba jedné linky nádrže rychlého míchání v hale filtrace F2 na nový meandr (1. stavba - 2. etapa),

— výstavba nového objektu filtrace s 16 ks filtrů s náplní GAU (2. stavba),
Tabulka 1. Filtraces GAU - přestavba 12 ks pískových filtrů v hale filtrace F2 - varianta II [2] Table 1. Filtration with GAC - reconstruction of 12 pcs sandfilters in F2 hall - variant II [2]

\begin{tabular}{lccc}
$\begin{array}{l}\text { Výkon filtrů } \\
\text { s GAU }\end{array}$ & $\begin{array}{c}\mathbf{Q}=\mathbf{3 , 5} \\
\mathrm{m}^{3} / \mathbf{s}\end{array}$ & $\begin{array}{c}\mathbf{Q}=\mathbf{3 , 0} \\
\mathbf{m}^{3} / \mathbf{s}\end{array}$ & $\begin{array}{c}\mathbf{Q}=\mathbf{2 , 5} \\
\mathrm{m}^{3} / \mathbf{s}\end{array}$ \\
\hline Počet filtrů & $12 \mathrm{ks}$ & $12 \mathrm{ks}$ & $12 \mathrm{ks}$ \\
\hline Plocha filtrů & $1182,6 \mathrm{~m}^{2}$ & $1182,6 \mathrm{~m}^{2}$ & $1182,6 \mathrm{~m}^{2}$ \\
\hline Filtrační rychlost & $10,65 \mathrm{~m} / \mathrm{hod}$ & $9,13 \mathrm{~m} / \mathrm{hod}$ & $7,61 \mathrm{~m} / \mathrm{hod}$ \\
\hline
\end{tabular}

Doba zdržení

$10,14 \mathrm{~min}$

$11,83 \mathrm{~min}$

$14,2 \min$

— výstavba čerpací stanice zajištujuící prececerpávání upravené vody na filtry s GAU (2. stavba)

- výstavba všech dalších souvisejících objektů - nového objektu trafostanice a rozvoden VN a NN, nových spojovacích rozvodů a prístupové komunikace (2. stavba)

- rekonstrukce 32 ks pískových filtrů v hale filtrace F1 (3. stavba),

- rekonstrukce 24 pískových filtrů v hale filtrace F2 (4. stavba).

Realizace 1. a 2. stavby se předpokládá do roku 2020, realizace 3. a 4. stavby do roku 2030. I realizací této varianty budou zachovány dvě samostatné technologické linky:

- linka prípravy suspenze $v$ objektu BUDAFLO a 32 ks pískových filtrů v hale filtrace F1,

- linka prípravy suspenze v hale filtrace F2 a 24 ks pískových filtrů v hale filtrace F2,

- pro obě linky by se využíval sorpční stupeň realizovaný v novém objektu s 16 ks filtrů s náplní GAU.

PInění návrhových parametrů sorpce na GAU při variantě III - filtry s náplní GAU - výstavba 16 ks filtrů s náplní GAU v novém objektu - výška náplně 1,7 m (2. stavba) - uvádí tabulka 2 .

Z tabulky 2 je zřejmé, že při realizaci varianty III budou splněny požadované technologické návrhové parametry uvedené jako vstupní a zásadní podmínky pro modernizaci a rekonstrukci úvŽ, přičemž se nesniží plocha pískových filtrů.

Varianta IIIa - technické řešení varianty IIla je obdobné jako u varianty III, avšak technologická linka filtrů s GAU v novém objektu by probíhala etapovitě první etapa zahrnuje pouze výstavbu objektu pro 8 ks filtrů s GAU. Variantní řešení Illa je cestou kompromisu, přičemž by se měla realizovat pouze část nového objektu filtrace s GAU, která by odpovídala aktuálním potřebám výroby pitné vody, tj. s výkonem 1,75-2,0 m³/s. To znamená, že by byla realizována nová hala pouze pro osm filtrů s tím, že by v budoucnosti, v případě potřeby, bylo možné doplnit zbývající potřebnou kapacitu filtrů s GAU. Písková filtrace bude zachována v současném rozsahu a bude možné bez výrazných provozních omezení pristoupit k její postupné rekonstrukci.

Součástí této varianty je:

- rekonstrukce stávajícího meandru v objektu BUDAFLO (1. stavba - 1. etapa),

- prestavba jedné linky nádrže rychlého míchání v hale filtrace F2 na nový meandr (1. stavba - 2. etapa),

- výstavba nového objektu filtrace s 8 ks filtrů s náplní GAU (2. stavba),

- výstavba čerpací stanice zajištujuící přečerpávání upravené vody na filtry s GAU (2. stavba)

- výstavba všech dalších souvisejících objektů - spojovací rozvody a prístupové komunikace (2. stavba),

- rekonstrukce 32 ks pískových filtrů v hale filtrace F1 (3. stavba),

— rekonstrukce 24 pískových filtrů v hale filtrace F2 (4. stavba). 
Tabulka 2. Filtry s náplní GAU - varianta III [2]

Table 2. Filters with GAC - variant III [2]

\begin{tabular}{lccc}
$\begin{array}{l}\text { Výkon filtrů } \\
\text { s GAU }\end{array}$ & $\begin{array}{c}\mathbf{Q}=\mathbf{3 , 5} \\
\mathbf{m}^{3} / \mathbf{s}\end{array}$ & $\begin{array}{c}\mathbf{Q}=\mathbf{3 , 0} \\
\mathbf{m}^{3} / \mathbf{s}\end{array}$ & $\begin{array}{c}\mathbf{Q}=\mathbf{2 , 5} \\
\mathbf{m}^{3} / \mathbf{s}\end{array}$ \\
\hline Počet filtrů & $16 \mathrm{ks}$ & $16 \mathrm{ks}$ & $16 \mathrm{ks}$ \\
\hline Plocha filtrů & $1604 \mathrm{~m}^{2}$ & $1604 \mathrm{~m}^{2}$ & $1604 \mathrm{~m}^{2}$ \\
\hline Filtrační rychlost & $7,0 \mathrm{~m} / \mathrm{hod}$ & $6,7 \mathrm{~m} / \mathrm{hod}$ & $5,6 \mathrm{~m} / \mathrm{hod}$ \\
\hline Doba zdržení & $12,1 \mathrm{~min}$ & $15,2 \mathrm{~min}$ & $18,2 \mathrm{~min}$ \\
\hline
\end{tabular}

Realizace 1. a 2. stavby se predpokládá do roku 2020, realizace 3. a 4. stavby do roku 2030. Realizací této varianty budou zachovány dvě samostatné technologické linky:

— linka prípravy suspenze v objektu BUDAFLO a 32 ks pískových filtrů v hale filtrace F1,

- linka prípravy suspenze v hale filtrace F2 a 24 ks pískových filtrů v hale filtrace F2,

— pro obě linky by se využíval sorpční stupeň realizovaný v novém objektu s 8 ks filtrů s náplní GAU.

Filtry s náplní GAU - výstavba 8 ks filtrů s náplní GAU v novém objektu výška náplně 1,7 m - plnění návrhových parametrư řešení uvádí tabulka 3.

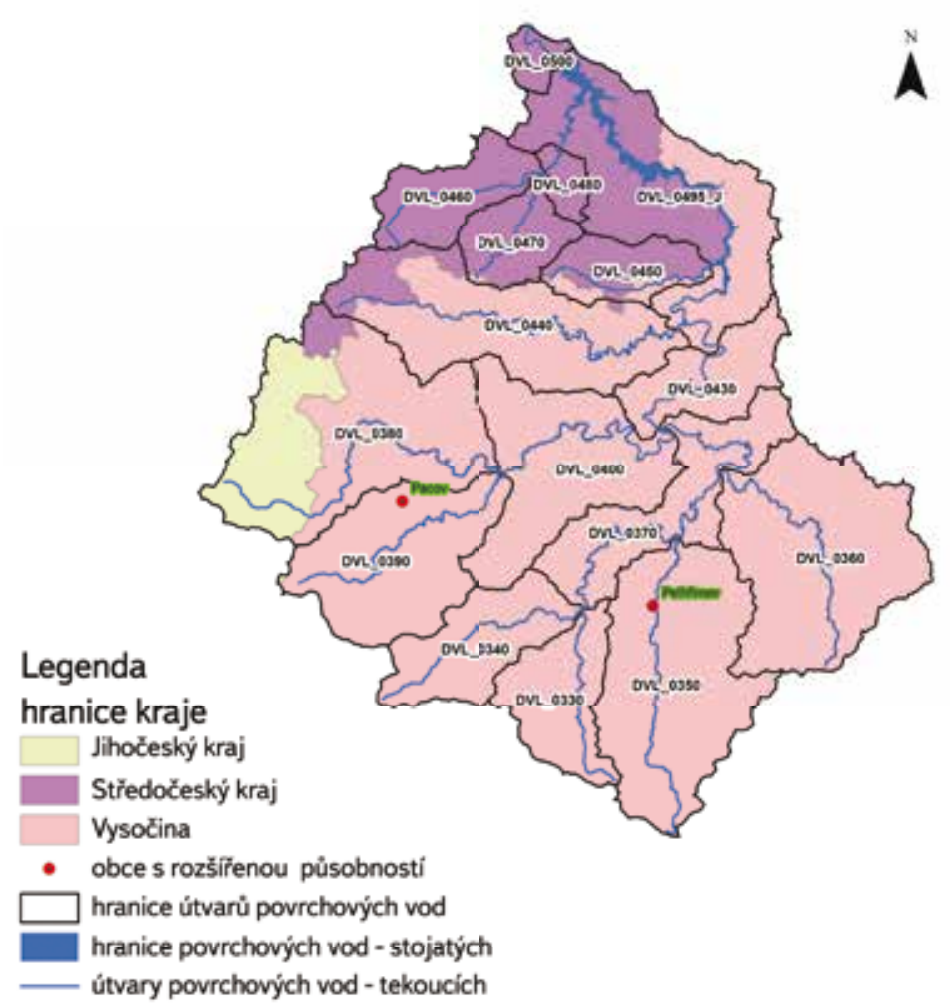

Obr. 2. Povodí vodárenské nádrže Švihov

Fig. 2. River basin of drinking water reservoir Švihov
Tabulka 3. Filtry s náplní GAU - varianta Illa [2] Table 3. Filters with GAC - variant IIIa [2]

\begin{tabular}{lcccc}
$\begin{array}{l}\text { Výkon filtrů } \\
\text { s GAU }\end{array}$ & $\begin{array}{c}\mathbf{Q}=\mathbf{2 , 0} \\
\mathbf{m}^{3} / \mathbf{s}\end{array}$ & $\begin{array}{c}\mathbf{Q}=1,75 \\
\mathbf{m}^{3} / \mathbf{s}\end{array}$ & $\begin{array}{c}\mathbf{Q}=1,5 \\
\mathbf{m}^{3} / \mathbf{s}\end{array}$ & $\begin{array}{c}\mathbf{Q}=1,2 \\
\mathbf{m}^{3} / \mathbf{s}\end{array}$ \\
\hline $\begin{array}{l}\text { Počet filtrů } \\
\text { Plocha filtrů }\end{array}$ & $802 \mathrm{~m}^{2}$ & $802 \mathrm{~m}^{2}$ & $802 \mathrm{~m}^{2}$ & $802 \mathrm{~m}^{2}$ \\
\hline $\begin{array}{l}\text { Filtrační } \\
\text { rychlost }\end{array}$ & $9 \mathrm{~m} / \mathrm{hod}$ & $7,9 \mathrm{~m} / \mathrm{hod}$ & $6,7 \mathrm{~m} / \mathrm{hod}$ & $5,4 \mathrm{~m} / \mathrm{hod}$ \\
\hline $\begin{array}{l}\text { Doba zdržení } \\
\text { 11,4 min }\end{array}$ & $13 \mathrm{~min}$ & $15,1 \mathrm{~min}$ & $18,9 \mathrm{~min}$ \\
\hline
\end{tabular}

Na základě hodnot v tabulce 3 nebude v rámci realizace varianty Illa zajištěno při průtoku větším než cca $1,75 \mathrm{~m} 3 / \mathrm{s}$ - plnění návrhových parametrů filtrační rychlosti (do 7 m/hod) a doby zdržení (min. 12 minut) pro filtry s GAU.

\section{PROVOZNÍ A BEZPEČNOSTNÍ RIZIKA NAVRŽENÝCH VARIANTNÍCH ŘEŠENÍ}

Otázka kvality vody odebírané z vodárenského zdroje (VN Švihov) je samozřejmě širší a nejde ji omezit jen na technická opatření, která řeší následný stav. Je zcela zjevné, že je souběžně zcela nezbytné se zapojit do aktivit, které se vytvářeji či fungují v okolí tohoto zdroje. Vzhledem k tomu, že celé povodí má přes 1175 km² a zasahuje do tři krajů, bylo by velmi krátkozraké se domnívat, že vše vyřeši jen ochranná pásma v těsném okolí VN Švihov. Co do struktury, tvoři 51,5\% orná půda, 30 \% lesy, 10 \% smíšená zemědělská oblast a 4,2 \% travní porost. Povodí VN Švihov je znázorněno na obr. 2.

Nejde zdaleka jen o dodržování a důslednou kontrolu agrotechnických postupů při aplikaci látek, které mohou negativně ovlivnit kvalitu vody ve zdroji, jak se diskuse mnohdy zužuje. To je jen základní předpoklad. Podstatnější je celkový citlivý prístup k území a vytvoření systému hospodaření s půdou tak, aby se voda generovaná z celé plochy co nejvíce zdržela v systému a do VN Švihov se dostávala s co nejmenšími koncentracemi nežádoucích polutantů. Toho Ize dosáhnout řadou opatření, mezi něž patří např́klad změna pěstovaných plodin, zalesňování, budování retenčních předzdrží, vytváření mokřadních systémů, rybníků, a také investicemi do čištění odpadních vod,

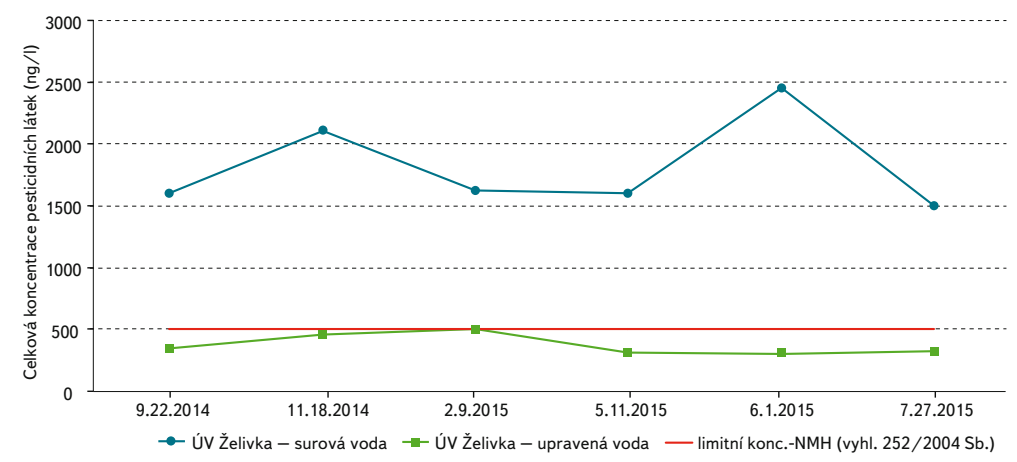

Obr. 3. Celkový obsah pesticidních látek v surové a upravené vodě v období 09/2014-08/2015 (zdroj: Želivská provozní, a. S., 2015)

Fig. 3. Total concentration of pesticides in raw and drinking water in period 09/2014-08/2015 (source: Želivská provozní, a. S., 2015) 
a to i z malých zdrojů. Vše je potřeba navazovat na Plán dílčího povodí Dolní Vltavy [5]. Lze zvažovat i otázku výkupu pozemků pro realizaci takovýchto trvalých opatření. To vše může vést k určitému snižení rizik spojených s upravitelností surové vody. Tato opatření však jsou naprosto nezbytná pro dlouhodobé trvalé udržení strategického zdroje zásob vody pro více jak 1,5 milionu obyvatel ČR. Zdroje pro navrhovaná opatření je potřeba hledat ve vícezdrojovém financování s možným zapojením i evropských zdrojů. I v prípadě aplikace potřebných opatření v povodí Želivky nelze ovšem očekávat okamžitý efekt, který by vedl k rychlým změnám v kvalitě a množství surové vody. Pozitivní vliv Ize predikovat $v$ řádu desítek let. Proto se musí orgány společnosti zabývat potřebnými kroky k zajištění bezpečné výroby vody v horizontu 20-30 let.

Je-li cílem modernizace úv Želivka dodržet požadavek a snižit koncentraci i nově sledovaných a možná v budoucnu zjištovaných látek v surové vodě a zabezpečit kvalitní vyráběnou pitnou vodu, je současná technologie jednostupňové úpravy vody koagulační filtrací na hraně svých možností. Pro snížení obsahu některých látek limitovaných v pitné vodě je zcela neúčinná (např. pesticidy a v budoucnu i léčiva, popř. další látky zařazené jako prioritní látky a zejména jejich mnohdy stabilnější metabolity). Vzhledem k vysokému obsahu pesticidních látek v odebírané surové vodě z VN Švihov existuje v budoucnu reálné riziko neplnění legislativních parametrů ve vyrobené pitné vodě. Tuto skutečnost dokumentuje graf na obr. 3, kde hodnota NMH (nejvyšší mezní hodnota) představuje limitní koncentraci 500 ng/l pro celkový obsah pesticidních látek v pitné vodě $[6,7]$.

Pro výrobu pitné vody z vody odebírané z VN Švihov existuje řada faktorů, které ovlivňují upravitelnost vody (poměr N, P, teplota, CHSK atd.), ale mezi kritické patři především dva parametry odebírané surové vody:

— obsah mikroorganismů - vykazované jako parametr mikroskopický obraz,

— výskyt pesticidů a jejich metabolitů.

V období jarního oživení dochází k opakovaným problémům s kvalitou upravené vody, kdy současné technologie nezabrání průniku mikroorganismů do filtrátu, a to ani živých. Tyto negativní jevy mají bohužel v posledních letech zvyšující se frekvenci. Ve stávajícím technologickém uspořádání dochází k průniku části mikroorganismů přes pískové filtry, které rovněž nedokáží odstranit z upravované vody pesticidní látky. Filtrát je pak veden na ozonizaci, kde dochází působením ozónu k "rozbití” zbylých mikroorganismů (vymývání obsahu buněk (sinic) do vody) a $\mathrm{k}$ fragmentaci pesticidů a jejich metabolitů. Dochází tak k nárůstu organického uhlíku ve vodě, resp. k tvorbě prekurzorů trihalometanů, a následnou chlorací vody může v průběhu transportu vody k odběratelům dojít ke zhoršení parametrů kvality vody. Výrazně se snižuje kvalita vyrobené vody v čase. Poněkud méně konfliktní situace je pak i v období podzimní cirkulace vody $\vee$ nádrži. Tato negativní období trvají zpravidla 3-5 měsíců v roce.

Pro dosažení separace naprosté většiny mikropolutantů je sorpční stupeň $\checkmark$ technologické lince úpravny nezastupitelný. Nezastupitelnost sorpčního stupně spočívá mj. také v tom, že sorpční stupeň nežádoucí látky z vody skutečně odstraňuje, zatímco ozonizace většinou může jen malou část prítomných organických látek oxidovat až na oxid uhličitý a vodu, ovšem z velké většiny z nich vytvoří jiné a těžko identifikovatelné látky. Proto je doporučeno doplnění stávající technologie o sorpční stupeň s GAU, resp. o nejlepší dostupnou technologii pro dosažení co nejvyššího zabezpečení kvality vyráběné pitné vody. Navrhovaná nová linka s filtry s náplní GAU má kromě asimilovatelného organického uhlíku (AOC), celkového organického uhlíku (TOC), biologicky degradabilního organického uhlíku (BDOC) zároveň odstranit z upravované vody především pesticidní látky a jejich metabolity, které není současná koagulační technologie schopna odstraňovat.

Problematická mohou být do budoucna i léčiva a jejich metabolity, hormony a xenobiotika, které sice nejsou doposud výrazně detekovány v odebírané surové vodě, ale podle realizovaných studií a měření ve světě, ale prrímo
Tabulka 4. Celkové zpưsobilé náklady a predpokládaná výše podpory jednotlivých variant [1]

Table 4. Total eligible costs and the estimated amount of financial support [1]

\begin{tabular}{lccc} 
Náklady (tis. Kč) & Varianta II & Varianta III & Varianta IIla \\
\hline 1. stavba & 67012 & 59905 & 59905 \\
\hline 2. stavba & 549079 & 994307 & 666656 \\
\hline Ostatní náklady (18\%) & 110896 & 189758 & 130781 \\
\hline $\begin{array}{l}\text { Celkové způsobilé } \\
\text { náklady }\end{array}$ & $\mathbf{7 2 6 9 8 7}$ & $\mathbf{1 2 4 3 9 7 0}$ & $\mathbf{8 5 7 3 4 2}$ \\
\hline $\begin{array}{l}\text { Předpokládaná výše } \\
\text { dotace (63,75\%) }\end{array}$ & 463454 & 793031 & 546556 \\
\hline $\begin{array}{l}\text { Vlastní } \\
\text { spolufinancování }\end{array}$ & 263533 & 450939 & 310786 \\
\hline
\end{tabular}

i v povodí VN Švihov, nedokáží běžné čistírenské technologie tyto látky v čistírnách odpadních vod (ČOV) odstraňovat. V souladu s kontinuálním vývojem možností a citlivostí analytických metod lze očekávat $v$ této oblasti zjištění nových znečištujících látek, následné zavedení jejich sledování a zpřísňování limitů pro látky sledované v současnosti.

Pokud se pokusíme shrnout bezpečnostní faktory, provozní a kvalitativní rizika navržených variant řešení modernizace úV Želivka, je zrejemé, že splnění prognóz a expertních odhadů vývoje spotřeb vody si budeme moci skutečně ověřit až za cca 40 let, ale o investici v navrženém rozsahu je potřeba rozhodnout již nyní. Výsledné rozhodnutí a výběr varianty modernizace bude z hlediska dalšího provozu úV Želivka již nevratné.

$\checkmark$ prípadě volby varianty II bude provedena rekonstrukce části pískových filtrů filtrace F2 a jejich prestavba na filtry s GAU, včetně výstavby čerpací stanice na GAU. Filtry budou stavebně a výškově upraveny tak, že již nebude možné je v budoucnosti bez větších zásahů provozovat jako pískové filtry. Celková filtrační plocha pískových filtrů se sníží. Při současném průměrném objemu vyrobené pitné vody a rekonstrukci BUDAFLO bude toto řešení při zachování současného množství vyrobené pitné vody postačovat. Provozní limity této varianty se projeví až v okamžiku, když se naplní předpokládaný narůst spotreby pitné vody a ÚV Želivka bude nutné provozovat dlouhodobě s vyššími výkony, popř. při havarijních a mimořádných situacích, které si vyžádají zvýšení výkonu ÚV Želivka. Již léto 2015 (horké a suché) a následně podzim 2015 s podprůměrnými srážkami ovlivnily výrobu pitné vody. Další dočasné snižení plochy pískových filtrů se předpokládá v průběhu realizace jejich rekonstrukce (3. a 4. stavba).

V prípadě volby varianty III, tj. výstavba nové haly filtrace GAU, se jedná o variantu, která bude mít ze současného pohledu větší provozní rezervy a bude dostatečně využita při předpokládaném nárůstu spotřeby vody, ale zejména při řešení krizových a mimořádných situací a v prípadě havarijních stavů, např. u ostatních zdrojů vodárenské soustavy. Provozní rezervy pískové filtrace F1 a F2 bude možné využít při rekonstrukcích pískových filtrů, které je nutné začít připravovat inned po dokončení 1. a 2. stavby modernizace úvŽ. Lze ríci, že z hlediska technologické spolehlivosti a stability i dostatečné kapacity pro prípadné zjištění výskytu dalších látek má tato varianta požadované provozní rezervy.

Při volbě redukované kompromisní varianty Illa bude realizována výstavba pouze části nové haly filtrace GAU, která bude odpovídat současným potřebám pitné vody, tj. s výkonem cca 1,75-2,0 m³/s. Byla by tedy realizována pouze část haly, která by se dala $v$ budoucnosti rozširíit o další potřebnou kapacitu 
filtrace s GAU, pokud se očekávaný nárůst spotřeby pitné vody či zhoršující se kvalita potvrdí. Plocha pískové filtrace bude zachována v současném rozsahu a bude možné bez výrazných provozních omezení přistoupit k její postupné rekonstrukci. Nevýhodou však zůstává skutečnost, že období, kdy je průměrné množství vyrobené pitné vody $\vee$ pásmu do $2,0 \mathrm{~m}^{3} / \mathrm{s}$, představuje $v$ posledních letech do 3 \% celkové roční výroby.

\section{MOŽNOSTI FINACOVÁNÍ MODERNIZACE ÚVŽ V RÁMCI OPŽP 2014-2020}

Projekt „Modernizace ÚV Želivka - sorpční stupeň” naplňuje podmínky Operačního programu Životní prostředí 2014-2020 a je vhodným projektem do specifického cíle 1.2 Zajistit dodávky pitné vody v odpovídající jakosti a množství.

Podle aktuální metodiky OPŽP 2014-2020 (Pravidla pro žadatele a príjemce podpory v Operačním programu Životní prostředí pro období 2014-2020, verze 4.0, účinné od 14. srpna 2015) se jako prijiatelné kvalifikují projekty, kterými dojde k napojení dalších obyvatel na kvalitní pitnou vodu (za předpokladu existence nebo současného vybudování vyhovujícího systému likvidace odpadních vod), ke zlepšení kvality dodávané pitné vody do vodovodní sítě nebo ke zvýšení množství dodávané pitné vody $[3,4]$.

Projekt modernizace úV Želivka je projektem přijatelným ve specifickém cíli 1.2 - Zajistit dodávky pitné vody v odpovídající jakosti a množství. V rámci tohoto specifického cíle 1.2 budou podporovány projekty zaměřené na: výstavbu a modernizaci úpraven vody a zvyšování kvality zdrojů pitné vody včetně výstavby a modernizace systémů (technická opatření) pro ochranu zdrojů pitné vody v jejich bezprostřední blízkosti, sloužící veřejné potřebě,

- výstavbu a dostavbu přivaděčů a rozvodných sítí pitné vody včetně souvisejicích objektů sloužících veřejné potřebě.

Citace pasáží z Programového dokumentu OPŽP 2014-2020, požadavky na projekty v oblasti zlepšování kvality pitné vody [4]:

„Prijiatelný projekt je ten, jehož realizací dojde k zabezpečení zásobování obyvatel pitnou vodou v dostatečném množství, popř. ve zlepšené kvalitě, nebo bude umožněno zásobování většího počtu obyvatel kvalitní pitnou vodou $v$ oblastech, kde dochází k neplnění požadavků na jakost surové vody dle směrnice 98/83/ES nebo kde Ize předpokládat postupné zhoršování kvantity i kvality vodních zdrojü. Intenzifikace úpraven vody pro účely dosažení potřebné kvality vyrobené pitné vody bude podporovatelná pouze v prípadě, že zlepšení kvality surové vody nebude v potřebném časovém horizontu nebo za ekonomicky prijatelných podminek dosažitelné."

Mezi oprávněnými príjemci v rámci specifického cíle 1.2 jsou také společnosti vlastněné z více než 50 \% majetku obcemi a městy nebo jinými veřejnoprávními subjekty, což úV Želivka naplňuje. Podpora bude poskytována formou dotace z prostředků Operačního programu Životní prostředí pro období 2014-2020 (OPŽP) s maximální hranicí do 85 \% celkových způsobilých výdajů projektů. U projektů vytvárejících príijmy podle čl. 61 obecného nařízení budou způsobilé výdaje určeny odečtením př́ijmů projektu metodou výpočtu flat rate (jednorázovým snížením způsobilých výdajů paušální sazbou 25 \%). Výše podpory v tomto prípadě činí $85 \% \times(100 \%-25 \%)=63,75 \%$. Porovnání způsobilých nákladů jednotlivých variant modernizace úv Želivka je uvedeno v tabulce 4.

Tabulka 5. SWOT analýza modernizace ÚV Želivka - varianta III [1] Table 5. SWOT analysis of modernization UV Želivka - variant III [1]

\section{Vnitřní faktory}

\section{SILNÉ STRÁNKY}

— spolehlivost plnění návrhových technologických parametrů - S1III

- optimální řešení zajištujující množství i kvalitu výroby pitné vody včetně plnění legislativních normativů - S2III

— výstavba nové linky a technologie - S3III

— spolehlivost provozu v krizových situacích a pokrytí bezpečnostních rizik - S4III

- možnost odstraňování i dalších látek - xenobiotika, farmaka a dalších specifických organických látek - S5III

— minimální zásahy do současné technologie pískové filtrace - S6III

— vysoká pravděpodobnost získání dotačních prostředků z OPŽP - nová stavba a technologie - O1III

- zajištění dostatečné rezervy pro odhadované množství vyrobené pitné vody v požadované kvalitě do roku 2050 - O2III

— zajištění rezervy pro prípad havarijních stavů a nutnosti odstavení ostatních zdrojü, krizových událostí, mimořádného zhoršení kvality surové vody apod. - O3III

\section{SLABÉ STRÁNKY}

— nejvyšší investiční a provozní náklady - W1III

- administrativní náročnost - samostatné územní ř́zení a nutnost realizace procesu EIA - W2III

PŘílEŽITOSTI

- kofinancování projektu z vlastních zdrojů - T11II

- riziko nízké alokace prostředků v rámci výzvy OPŽP - T2III

- riziko současně probíhající investiční akce v oblasti vodního hospodárství - T3III

- riziko velikosti projektu z hlediska podmínek OPŽP - T4III

- navýšení ceny vody predané - T5III

HROZBY

\section{Vnější faktory}


Tabulka 6. Vyhodnocení SWOT analýzy - varianta III [1]

Table 6. SWOT analysis - evaluation - variant III [1]

\begin{tabular}{|lccc|}
\hline & Váha & Body & Výsledek \\
\hline SILNÉ STRÁNKY & & & \\
\hline S1III & 0,1 & 4 & 0,4 \\
\hline S2III & 0,2 & 4 & 0,8 \\
\hline S3III & 0,1 & 4 & 0,4 \\
\hline S4III & 0,1 & 5 & 0,5 \\
\hline S5III & 0,4 & 5 & 2,0 \\
\hline S6III & 0,1 & 4 & 0,4 \\
\hline součet & $\mathbf{1 , 0}$ & & $\mathbf{4 , 5}$ \\
\hline
\end{tabular}

\section{SLABÉ STRÁNKY}

\begin{tabular}{lccc}
\hline W1III & 0,9 & -4 & $-3,6$ \\
\hline W2III & 0,1 & -2 & $-0,2$ \\
\hline součet & $\mathbf{1 , 0}$ & & $\mathbf{- 3 , 8}$ \\
\hline
\end{tabular}

\section{PŘíLEŽITOSTI}

\begin{tabular}{llll}
\hline O1III & 0,3 & 4 & 1,2 \\
\hline O2III & 0,4 & 5 & 2,0 \\
\hline O3III & 0,3 & 5 & 1,5 \\
\hline součet & $\mathbf{1 , 0}$ & & $\mathbf{4 , 7}$
\end{tabular}

\section{HROZBY}

\begin{tabular}{llll|}
\hline T1III & 0,1 & -5 & $-0,5$ \\
\hline T2III & 0,2 & -4 & $-0,8$ \\
\hline T3III & 0,3 & -3 & $-0,9$ \\
\hline T4III & 0,3 & -3 & $-0,9$ \\
\hline T5III & 0,1 & -3 & $-0,3$ \\
\hline součet & $\mathbf{1 , 0}$ & & $\mathbf{- 3 , 4}$ \\
\hline Interní faktory & & & $+0,7$ \\
\hline Externí faktory & & & $+1,3$ \\
\hline Výsledná bilance & & & $\mathbf{+ 2 , 0}$ \\
\hline
\end{tabular}

\section{SWOT ANALÝZA - VÝSLEDKY A DISKUSE}

Vyhodnocení SWOT analýzy variant řešení modernizace ÚV Želivka je následující:

Interní část - silné a slabé stránky

- výčet silných a slabých stránek, jde o klasický soupis kladů a záporů každé z variant řešení, pro bodování použijeme kladnou stupnici 1-5 s tím, že 5 znamená nejvyšší spokojenost a 1 nejnižší spokojenost.

Externí část - týká se okolního prostředí

- príležitosti, které nám okolí nabízí, a proti nim jsou uvedeny hrozby, které nás z okolí ohrožují. Pro bodování použijeme zápornou stupnici od -1 (nejnižší nespokojenost) až po -5 (nejvyšší nespokojenost).

Váha jednotlivých položek $v$ dané kategorii musí v součtu být 1,0, přičemž vždy platí, že čím vyšší číslo, tím větší důležitost položky v dané kategorii a naopak. Príklad vyhodnocení SWOT analýzy pro vítěznou variantu modernizace ÚV Želivka je uveden v tabulce 5.

$\checkmark$ tabulce 5 byly faktory převedeny do hodnotící tabulkové matice, která umožní vyhodnotit přislušnou variantu. Příklad vyhodnocení pro variantu III je uveden v tabulce 6 .

Z výsledné bilance interních a externích faktorů vyplývá, že interní i externí faktory vykazují kladnou bilanci hodnocení. Můžeme tedy konstatovat, že při volbě VARIANTY III převažují silné stránky a príležitosti.

Souhrnné výsledky SWOT analýzy jednotlivých navržených variant modernizace Úv Želivka uvádí tabulka 7.

Z výše uvedené SWOT analýzy posuzovaných variantních řešení modernizace ÚV Želivka se doporučuje realizovat modernizaci technologie výroby pitné vody na ÚV Želivka doplněním o filtry s GAU podle VARIANTY III.

\section{KRITERIÁLNÍ ANALÝZA MODERNIZACE ÚVŽ}

Jako vhodná alternativa k výše uvedené SWOT analýze a současně i její kontrola může být využita kriteriální analýza navržených variant řešení modernizace úvŽ z pohledu plnění definovaných kritérií:

— spolehlivost výroby pitné vody (množství a kvalita vyrobené pitné vody) - K1,

- spolehlivosti provozu - K2,

- plnění návrhových parametrů filtrace, resp. sorpce na GAU (objem vyrobené pitné vody, filtrační rychlost a doba zdržení) - K3,

- minimální investiční náklady - K4,

- minimální provozní náklady - K5,

- minimální čisté současné hodnoty nákladů - K6,

- finanční podpora v rámci OPŽP - K7,

- rizika a zajištění spolehlivosti provozu technologie během realizace stavby - K8,

- nutnost současné realizace dalších návazných staveb - K9,

- plnění legislativních a ekologických normativů - K10,

- vytvoření nutné rezervy pro odhad růstu spotřeby pitné vody v Praze - K11,

— zajištění spolehlivosti provozu v prípadě mimořádných událostí - K12,

— administrativní náročnost procesu prípravy a realizace projektu - K13.

V tabulce 8 je uveden prehled hodnocených kritérií a pořadí umístění jednotlivých variant řešení modernizace úv Želivka.

Z výsledků kriteriální analýzy jednotlivých posuzovaných variant rešení modernizace úv Želivka vyplývá, že nejlépe splňuje požadovaná kritéria VARIANTA III (tabulka 8). 
Tabulka 7. Souhrn výsledků SWOT analýzy [1]

Table 7. SWOT analysis - summary results [1]

\section{Varianta}

\section{Celková bilance}

\section{Výsledné pořadí variant}

\begin{tabular}{lll}
\hline$\|$ & $-0,4$ & 2. \\
\hline$\| I$ & $+2,0$ & 1. \\
\hline IIIa & $-1,0$ & 3. \\
\hline
\end{tabular}

Tabulka 8. Kriteriální analýza variant řešení modernizace úv Želivka [1] Table 8. The UV Želivka modernization - objective analysis of alternative solutions [1]

\begin{tabular}{llcl} 
Kritérium & Varianta II & Varianta III & Varianta IIIa \\
\hline K1 & 2. & 1. & 3. \\
\hline K2 & 3. & 1. & 2. \\
\hline K3 & 2. & 1. & 3. \\
\hline K4 & 1. & 3. & 2. \\
\hline K5 & 2. & 3. & 1. \\
\hline K6 & 2. & 3. & 1. \\
\hline K7 & 3. & 1. & 2. \\
\hline K8 & 3. & 1. & 2. \\
\hline K9 & 3. & 1. & 2. \\
\hline K10 & 2. & 1. & 2. \\
\hline K11 & 3. & 1. & 2. \\
\hline K12 & 3. & 1. & 2. \\
\hline K13 & 1. & 3. & 21 \\
\hline Celkový součet & 30 & $\mathbf{1 .}$ & 27 \\
\hline pořadí & $\mathbf{3 .}$ & & 2. \\
\hline Výsledné pořadí & & 2. & 2. \\
\hline
\end{tabular}

\section{ZÁVĚR}

Na základě výše provedené SWOT analýzy a výsledků kriteriální analýzy modernizace technologie výroby pitné vody na Úpravně vody Želivka doporučujeme realizovat modernizaci podle VARIANTY III.

Tato varianta řešení modernizace ÚV Želivka s sebou v budoucnu přinese zejména následující pozitivní skutečnosti:

— zajištění potřebného množství pitné vody v požadované kvalitě s ohledem na rizikové scénáře klimatické změny;

— zajištění potřebného množství pitné vody v požadované kvalitě vzhledem k vývoji růstu počtu obyvatel zásobované oblasti;

— zajištění dostatečné rezervy výroby pitné vody $\vee$ požadovaném množství a kvalitě v prípadech krizových a mimořádných situacích v rámci Středočeské vodárenské soustavy a zásobování obyvatel Prahy pitnou vodou;

— dlouhodobé zajištění plnění legislativních požadavků na kvalitu vyrobené pitné vody, pokud jde o obsah mikroorganismů a pesticidů a jejich reziduí (a to i s ohledem na prípadné zjištění výskytu dalších znečištujících látek - farmaka, xenobiotika apod.), a to i prì potenciálním zhoršení kvality odebírané surové vody z VN Švihov;

- možnost financování velmi podstatné části projektu modernizace ÚV Želivka prostřednictvím finančních prostředků alokovaných v rámci OPŽP 2014-2020 - Prioritní osa 1 v rámci specifického cíle 1.2, pričcemž se s největší pravděpodobností jedná o poslední možnost finanční podpory projektů obdobného charakteru prostřednictvím dotačních prostředků EU;

- minimalizaci provozních problémů a rizik prípadných víceprací při samotné stavební realizaci;

— zajištění plnění definovaných návrhových parametrů technologie - množství vyrobené vody, filtrační rychlost a doba zdržení;

- umožní realizovat $v$ horizontu prišších 10-15 let postupnou rekonstrukci stávajících pískových filtrů v hale F1 a F2;

- navrhované rešení bude nepochybně nedílnou součástí širšího souboru komplexních opatření pro zajištění kvality pitné vody $\vee$ celém povodí VN Švihov pro budoucí generace.

Na druhé straně je nutné rovněž upozornit na nevýhody a rizika realizace této varianty modernizace, které spočívají zejména v:

- investičních a provozních nákladech - investičněa provozně se jedná o nejdražší z navrhovaných variant, s tím souvisejí i vyšší náklady na kofinancování projektu z OPŽP 2014-2020,

- navýšení ceny vody předané,

- riziku dopadů do cenotvorby pro hlavní město Prahu jako majoritního akcionáre společnosti Úpravna vody Želivka, a. s., a to zejména vzhledem k současné realizaci projektu modernizace a intenzifikace ÚČOV Praha.

Ke zvolené variantě modernizace úv Želivka vydala $v$ prosinci 2015 souhlasné stanovisko s doporučením k její realizaci odborná komise SOVAK ČR. Výsledná varianta byla rovněž doporučena k realizaci Komisí pro koordinaci investiční strategie vlastníků infrastruktury - KISVI Pražské vodohospodářské společnosti, a. s. Závěrem je potřeba připomenout, že modernizace úv Želivka je zásadním a kličovým krokem dalšího rozvoje společnosti a představuje naplňování proaktivní politiky při zabezpečování budoucího zásobování kvalitní pitnou vodou v dostatečném množství pro podstatnou část ČR. Současně se pravděpodobně jedná o poslední možné období, kdy lze ještě pro tuto potřebnou modernizaci použít dotační financování z fondů EU. 


\section{Poděkování}

Závěrem si dovoluji poděkovat všem členům projektovému týmu, kteři se spolupodíleli na realizaci výše uvedené SWOT analýzy modernizace ÚVŽ. Tento projektový tým pracoval ve složení: Ing. Václav Podhorský, Ph.D., Ing. Josef Parkán, Ing. Ondřej Syrǔček, MBA, Ing. Radek Lanč, RNDr. Pavel Policar, Ph.D., Ing. Karel Prajer, Ing. Petr Stehlík, Ing. Ladislav Sommer a Ing. Michal Fiala. Dále bych chtěl rovněž poděkovat zaměstnancům provozně-technického úseku Úpravny vody Želivka za součinnost a ochotu spolupracovat při zpracování SWOT analýzy.

\section{Literatura}

[1] TUŠIL, P. a kol. SWOT analýza variant řešení modernizace úpravny vody Želivka. Praha, řijen 2015.

[2] Príprava a modernizace ÚV Želivka - studie souboru staveb (PL 1401401). Praha: Sweco Hydropreojekt, listopad 2014.

[3] Programový dokument - Operační program Životni prostředí2014-2020, 1. verze z 30. 4. 2015

[4] Pravidla pro žadatele a př́iemce podpory v Operačním programu Životní prostředípro období2014-2020, verze 4.0, platná od 14. 8. 2015

[5] Plán dilčího povodí Dolní Vltavy. Praha: Povodí Vltavy, 2015

[6] Vyhláška č. 252/2004 Sb. ze dne 22. dubna 2004, kterou se stanoví hygienické požadavky na pitnou a teplou vodu a četnost a rozsah kontroly pitné vody, ve znění pozdější předpisů.

[7] Směrnice Rady 98/83/ES ze dne 3. listopadu 1998 o jakosti vody určené k lidské spotřebě

\section{Autor}

Ing. Petr Tušil, Ph.D., MBA

凶petr_tusil@vuv.cz

Výzkumný ústav vodohospodářský T. G. Masaryka, v. v. i., pobočka Ostrava

Příspěvěk prošel lektorským řízením.

\section{THE WATER TREATMENT PLANT \\ IN ŽELIVKA - SWOT ANALYSIS OF RECONSTRUCTION AND MODERNIZATION}

\section{TUSIL, $P$.}

TGM Water Research Institute, p. r. i., Ostrava branch

Keywords: SWOT analysis - drinking water treatment plant granular activated carbon - modernization - reconstruction

SWOT Analysis is a technique used to identify Strengths, Weaknesses, Opportunities and Threats related to a certain project, type of business, business plan, strategic investment, policy (meant as a measure), etc. This method of analysis is predominantly applied in marketing, but also in policy analysis and development. It enables organisations to evaluate their overall performance from all angles and to find challenges or new opportunities for growth. Furthermore, it is a part of company's strategic (long-term) planning. SWOT analysis has been performed with the aim to evaluate proposed and defined options of technical solution of Želivka drinking water treatment plant reconstruction and concurrently to create a relevant basis for the following decisions to be made by statutory body members, both of Úpravna vody Želivka, a. s., as an owner and Želivská provozní, a. s., as an operator, during their negotiations on an investment and operation strategy for the next 10-15 years. In our case, SWOT analysis has been used in decision-making process for selecting the most appropriate option of reconstruction of raw water treatment technological line at Želivka drinking water treatment plant. As a result of SWOT analysis, all individual options have been assessed for their suitability to be used as the best solution of the granular activated carbon absorption line to be implemented and integrated into drinking water production technology at Želivka drinking water treatment plant. 